\title{
The Influence of Inflation and Interest Rates on Working Capital Credit of Micro Small and Medium Enterprises
}

\author{
Aris Munandar* \\ Program Study of Management \\ Institute of Economic Science of Bima \\ Bima, Indonesia \\ aris.stiebima@gmail.com \\ Mistar Mistar \\ Program Study of Management \\ Institute of Economic Science of Bima \\ Bima, Indonesia
}

\author{
M. Rimawan \\ Program Study of Management \\ Institute of Economic Science of Bima \\ Bima, Indonesia \\ Nurul Huda \\ Program Study of Management \\ Institute of Economic Science of Bima \\ Bima, Indonesia
}

\begin{abstract}
This study aims to examine the influence of inflation and interest rates on the distribution of working capital credits for Micro Small and Medium Enterprises (MSMEs) in West Nusa Tenggara Province (NTB). The study was conducted at Central Bureau of Statistics (BPS) and Bank Indonesia (BI) in West Nusa Tenggara Province with the literature study method and documents through the official website. The total population is taken during 10 years from 2009 to 2018 . The samples are taken during 8 years from 2011 to 2018 . The sampling technique used was purposive sampling technique. The analysis technique used was Predictive Analytics Software (SPSS) version 23. The results of the study showed that the inflation and interest rates have an influence on the distribution of working capital credits to Micro Small and Medium Enterprises (MSMEs) in West Nusa Tenggara Province (NTB). The influence of inflation and interest rates is not very significant on the distribution of working capital credit for Micro Small and Medium Enterprises (MSMEs) in West Nusa Tenggara Province (NTB). The inflation has a positive effect and interest rate has a negative effect on the distribution of working capital credits for Micro Small and Medium Enterprises (MSMEs) in West Nusa Tenggara Province (NTB).
\end{abstract}

Keywords - inflation, working capital credits, interest rates.

\section{INTRODUCTION}

Micro Small and Medium Enterprises (MSMEs) in the province of West Nusa Tenggara has increased every year. The growth and development of Micro Small and Medium Enterprises (MSMEs) give a positive effect on the economy in West Nusa Tenggara. Based on data obtained through the official website of the Cooperative Office of MSMEs in West Nusa Tenggara Province, the number of MSMEs registered up to December 2018 was 649,987 MSMEs. The number has increased from 648,827 MSMEs in the previous year. The increase of MSMEs growth that occurred is still very low. One of the factors that influence the improvement of MSMEs is still very low is the amount of credit distribution.

The segment of MSMEs credit in West Nusa Tenggara Province in 2013 was $94.49 \%$. The development of credit distribution by commercial banks in NTB is still dominated by distributed for the MSME credit segment reaches $94.00 \%$. Based on its credit scale, MSME distributing for commercial banks is dominated by small credits that reach IDR 10.54 trillion with a segment of $60.55 \%$. Then followed by microcredit that reaches IDR 2.74 trillion with a market segment reached $15.73 \%$. While the segment of medium credit amounting to $17.72 \%$ or in nominal terms reached IDR 3.09 trillion [1]. The MSME credits distributed by commercial banks in NTB Province in 2016 were increased by $15.46 \%$ from 2015. The majority of MSME credit distributed by commercial banks is working capital credits, which is $78 \%$, and the rest of it is an investment credit amounting to $22 \%$ [2].

The working capital credits that distributed in 2016 to 2018 or the last 3 years have increased. In 2013 the number of working capital credits that distributed was IDR $8,968,000,000,000$, in 2017 IDR 10,400,000,000,000, and in 2018 in the amount of IDR $11,347,000,000,000$. The increase in working capital credits that distributed by the government through the banks to MSMEs in West Nusa Tenggara Province is still relatively small when compared to other provinces [3].

The growth and development of working capital credits in West Nusa Tenggara is affected by inflation and interest rates. There is an increase in inflation that occurred during the last 3 years. Based on the data obtained from the Central Bureau of Statistics Nusa Tenggara Barat, it is shown that the inflation in 2016 amounted to $2.61 \%$, in 2017 it was $3.70 \%$, and in 2018 it fell to $3.16 \%$. Inflation that occurred during the last 3 years is still in the category of low inflation. Based on data obtained through the official website of Bank Indonesia, it was found that interest rates over the last 3 years showed a fluctuating trend. In 2016 it was $5.11 \%$, in 2017 it was $4.96 \%$, and in 2018 it was $5.48 \%$.

The purpose of this study is to examine the effect of inflation and interest rates on working capital credits 


\section{LITERATURE REVIEW}

\section{A. Working Capital Credit}

Working capital credit is credit that used to fulfill the company requirements in order to increase the productions and operations. Working capital credit can also be interpreted as a type of credit provided by banks to debtors to fulfill their working capital requirements with a maximum repayment period of one year that can be used to finance inventory, accounts receivable, purchase of raw materials or other corporate working capital requirements. For working capital credit, the bank provides working capital credit facilities for small-scale enterprises (credit limit of up to IDR 500 million) and medium-scale enterprises (credit limit above IDR 500 million to IDR 5 billion). Working capital credit that provided aim to increase the production both in quantitative and qualitative improvements [4].

\section{B. Inflation}

Inflation is a sustained increase in the general price level of goods and services in an economy over a period of time. The price increase of just one or two items is not called inflation, except if the increase is widespread or lead to an increase in most of the other prices, like the prices of foods, beverages, cigarettes and tobacco, clothing prices, health and education costs, recreation and sports, transportation, communication, and financial services. From this definition, there are three components that must be completed in order to be able to say the inflation occurred, that are increases in price, generally happen and ongoing process [5].

Inflation can affect the effect on income, the effect on efficiency, and the effect on output. Inflation can cause an increase in production. If the increase in the price of goods occurs before the increase in wages, the profits of the business people will increase and it will encourage the increase of production. However, if the inflation rate is high enough then it will have the opposite effect, such as the decrease in output [6]

There are several policies to overcome the inflation, namely fiscal policy by increasing taxes and reducing government spending, monetary policy by raising interest rates and restricting credit and the basic terms of the offer, by performing steps that can reduce production costs and stabilize prices, such as reducing import taxes, price fixing, promote the increase of production and promote the development of technology [7].

\section{Interest Rate}

The interest rate is the interest rate of the securities short-term debt instruments denominated in rupiah issued by Bank Indonesia. Interest rates always fluctuate according to the policies of the Board of Governors of Bank Indonesia which are adjusted to the state of the Indonesian economy. Bank Indonesia uses the interest rate as one of the instruments to control inflation. Changes in SBI interest rates will have an effect on capital markets and financial markets [8].

\section{RESEARCH METHODS}

The type of data used in this study is quantitative data with research variables involving inflation, interest rates, and working capital credit. Data in this study were collected through literature study and documents. The study was conducted at Central Bureau of Statistics (BPS) and Bank Indonesia (BI) in West Nusa Tenggara Province and the research data was obtained through the official website of Central Bureau of Statistics (BPS) and Bank Indonesia (BI) in West Nusa Tenggara Province. Total population is taken during 10 years from 2009 - 2018. The sampling technique used was purposive sampling, namely non-random sampling technique. The research sample is taken for 8 years from 2011 - 2018. The available complete data on the official website is 8 years. The data needed in the form of distribution working capital for MSMEs, interest rates, and inflation in NTB Province. The data analysis tool in this study uses multiple linear regressions with Predictive Analytics Software (SPSS) version 23 for windows. The stages of testing by performing classical assumption test, multiple regression analysis, hypothesis testing. The hypotheses in this study are:

H1 : Inflation affects the distribution of working capital credit for MSMEs in West Nusa Tenggara Province

H2 : Interest Rates affect the working capital credit distribution for MSMEs in West Nusa Tenggara Province.

\section{RESULTS AND DISCUSSION}

TABLE I. RESUlTS OF MULTIPLE REGRESSION ESTIMATES

\begin{tabular}{|l|c|c|c|c|c|}
\hline Model & \multicolumn{2}{|c|}{$\begin{array}{c}\text { Unstandardized } \\
\text { Coefficients }\end{array}$} & $\begin{array}{c}\text { Standardized } \\
\text { Coefficients }\end{array}$ & $\mathrm{t}$ & Sig. \\
\hline & $\mathrm{B}$ & $\begin{array}{c}\text { Std. } \\
\text { Error }\end{array}$ & Beta & & \\
\hline Constant) & 30.837 & .519 & & 59.366 & .000 \\
\hline Inflation & .083 & .039 & .738 & 2.108 & .089 \\
\hline $\begin{array}{l}\text { Interest } \\
\text { Rate }\end{array}$ & -.208 & .095 & -.768 & -2.193 & .080 \\
\hline
\end{tabular}

Source: SPSS 23 output (2019)

Table 1 above shows that the magnitude of the constants in multiple linear equations is 30.837 and the coefficient of the inflation variable is 0.083 , the interest rate variable is 0.208 . Based on the above value can be created a regression equation as follows:

$W C C=30,8370.083$ Inflation -0,208 Interest Rates

The results of the regression equation above can be explained as follows:

- The constant value of 30.837 shows the value of working capital credit that is distributed at a fixed rate of inflation and fixed interest rates.

- The coefficient of inflation is 0.083 , it means that if inflation increase by 1 percent it will increase working capital credit by 0.083 . Likewise, if inflation downfall by 1 percent it will reduce working capital credit amounting to 0.083 .

- The coefficient of interest rates is -0.208 , it means that if interest rates increase by 1 percent it will reduce 
working capital loans by -0.208 . Likewise, if interest rates downfall by 1 percent will increase working capital credit amounting to 0.083 .

\section{A. Determination Coefficient Test Results (R2)}

TABLE II. MODEL SUMMARY

\begin{tabular}{|c|c|c|c|c|}
\hline Model & $\mathrm{R}$ & R Square & $\begin{array}{c}\text { Adjusted R } \\
\text { Square }\end{array}$ & $\begin{array}{c}\text { Std. Error of the } \\
\text { Estimate }\end{array}$ \\
\hline 1 & $.742^{\mathrm{a}}$ & .550 & .370 & .21841 \\
\hline \multicolumn{3}{|c|}{ a. Predictors: (Constant), Interest Rates, Inflation } \\
\hline
\end{tabular}

Based on Table 2 above, the coefficient of determination of the multiple linear regression equation is 0.550 . If multiplied by 100 percent, a value of 55.00 percent will be obtained. This value shows that the independent variable consisting of inflation and interest rates can explain the distribution of working capital credit of 55.00 percent and the remaining 45.00 percent is explained by other variables that are not used in this study.

\section{B. $\quad$ Statistical Test Results}

TABLE III. F TEST RESULTS

\begin{tabular}{|l|r|r|r|r|c|}
\hline \multicolumn{1}{|c|}{ Model } & \multicolumn{1}{c|}{$\begin{array}{c}\text { Sum of } \\
\text { Squares }\end{array}$} & \multicolumn{1}{c|}{ df } & $\begin{array}{c}\text { Mean } \\
\text { Square }\end{array}$ & F & Sig. \\
\hline Regression & .291 & 2 & .146 & 3.055 & $.136^{\mathrm{b}}$ \\
\hline Residual & .239 & 5 & .048 & & \\
\hline Total & .530 & 7 & & & \\
\hline
\end{tabular}

Dependent Variabel: working capital credit

Predictors: (Constant), Interest Rates, Inflation

Source: SPSS 23 output (2019)

Based on Table 3 above, the statistical $F$ test results obtained is the statistical $\mathrm{F}$ test probability value of 0.136 which is greater than the significant level used of $(\alpha=$ 0.05). Overall inflation and interest rates affect the distribution of working capital credit, with a value that is not too significant.

\section{The Effect of Inflation on Working Capital Credit Distribution}

The higher of inflation will affect the distribution of working capital credit. The results of previous studies indicate that inflation has a negative and significant effect on credit distribution [9]. Other research results state that inflation has a negative and significant effect on lending [10]. The results of other studies found that inflation has a positive and not significant effect on lending [11].

The inflation rate tends to have a significant effect on working capital credit. This shows that the increase or decrease in inflation will affect the distribution of bank working capital credit. The cause of this inflation is due to the shift in the aggregate supply curve towards the top left. The factors that cause the aggregate supply curve to shift are due to rising prices of production factors (whether from domestic or overseas) in the factor market, thus causing price increases in this market called cost-push inflation. In the case of cost push inflation, the price increases are often followed by business exhaustion [12].
Based on table 1, the statistical t test value for the inflation variable is obtained with a significance value of 0.089 greater than $(\alpha=0.05)$. It can be concluded that inflation has a positive and not significant effect on the distribution of working capital credit to MSMEs in West Nusa Tenggara Province (NTB). It means that inflation that occurred during 2011-2018 had a not too big influence on the distribution of working capital credit for MSMEs in West Nusa Tenggara Province (NTB). This is due to inflation that occurred in West Nusa Tenggara Province (NTB) in 2011-2018 is still in the category of light inflation.

\section{The Effect of Interest Rates on Working Capital Credit Distribution}

Interest rates represent borrower costs for the earned loans by lenders for investment. Interest rates are likely to have a negative influence on the working capital credit distribution [13]. The amount of interest will affect a person's decision to use money to spend or save. The higher the interest rate, the less willing to make an investment [6]. The provisions of interest rates that are too high will make business people or MSMEs reluctant to borrow and who had borrowed were unable to repay [14]. Interest rates have a negative and partially significant effect on credit distribution in Denpasar [15]. Interest rates have a positive and significant relationship to the distribution of working capital credit for MSMEs in South Sumatra Province [16]. Other studies have shown that SBI affects the distribution of MSME credit [17].

Based on table 1 , the value of the statistical t test for variable interest rates is -2.193 with a significance value of 0.080 greater than $(\alpha=0.05)$. It can be concluded that interest rates have a negative and not significant effect on the distribution of working capital credit to MSMEs in West Nusa Tenggara Province (NTB). It means that interest rates during 2011-2018 did not have a big influence on the distribution of working capital credit to MSMEs in West Nusa Tenggara Province (NTB). If interest rates increase, the distribution of working capital credit will decrease

\section{CONCLUSIONS AND SUGGESTIONS}

From the results of the analysis it can be concluded that inflation and interest rates have an influence on the distribution of working capital credit for MSMEs in West Nusa Tenggara Province (NTB). The effects of inflation is not too significant on the distribution of working capital credit for MSMEs in West Nusa Tenggara Province (NTB), this is because the inflation that occurred in West Nusa Tenggara Province (NTB) is still in the category of light inflation.

Interest rates do not has a significant effect on the distribution of working capital credit for MSMEs in West Nusa Tenggara Province (NTB). The influence of interest rates on the distribution of working capital credit for MSMEs in the Province of West Nusa Tenggara (NTB) has an inverse effect. It means that if the interest rates increase, the distribution of working capital credit will decrease and the other way around. The average of interest rate growth is still in the low category, so it does not has a 
significant influence on the distribution of working capital credit for MSMEs.

The limitation of this study is that it only takes samples from 2011-2018 and only finds out at inflation and interest rates without finding the other factors such as company size, economic growth, GRDP, and other factors.

Suggestions for further researchers is to use data for more than 10 years and analyze other factors such as company size, economic growth, the GRDP to measure the distribution of working capital credit for MSMEs. In addition, the participation of the Government is needed in order to facilitate MSMEs regarding funding to distribute working capital credit in order to able increases every year.

\section{REFERENCES}

[1] [1] Bank Indonesia, Laporan Ekonomi Mingguan, 13/4/2019. 2019.

[2] bank indonesia, Kajian Ekonomi dan Keuangan Regional Provinsi Nusa Tenggara Barat, Mataram: Bank Indonesia Representative Office, West Nusa Tenggara Province. 2016.

[3] Bank Indonesia, Laporan Ekonomi Mingguan, 13 April. 2019.

[4] I. B. Suhardjono, "Akuntansi Perbankan," Jakarta: Salemba Empat, 2006

[5] D. Boediono, "Teori Pertumbuhan Ekonomi, Edisi Pertama." Yogyakarta, 2012.

[6] E. M. Nopirin, "Buku 1," Yogyakarta BPFE UGM, 1998.

[7] S. Sukirno, "Makroekonomi Teori Pengantar (Ketiga ed.)," Jakarta Rajawali Pers, vol. 82, 2011.

[8] A. A. Witjaksono, "Analisis Pengaruh Tingkat Suku Bunga SBI, Harga Minyak Dunia, Harga Emas Dunia, Kurs Rupiah, Indeks Nikkei 225, dan Indeks Dow Jones terhadap IHSG (studi kasus pada IHSG di BEI selama periode 2000-2009)." UNIVERSITAS DIPONEGORO, 2010.

[9] P. Sharma and N. Gounder, "Determinants of bank credit in small open economies: The case of six Pacific Island Countries," Available SSRN 2187772, 2012

[10] M. S. Nazir, M. M. Nawaz, and U. J. Gilani, "Relationship between economic growth and stock market development," African J. Bus. Manag., vol. 4, no. 16, p. 3473, 2010.

[11] N. M. J. Sari and N. Abundanti, "Pengaruh DPK, ROA, Inflasi dan Suku Bunga SBI Terhadap Penyaluran Kredit Pada Bank Umum," E-Jurnal Manaj., vol. 5, no. 11, 2016.

[12] Weni, "Analisis Pengaruh Inflasi, PDRB, dan NPL terhadap Penyaluran Kredit Modal Kerja Bank Umum di Provinsi Kalimantan Barat Periode 2005-2015," J. Untan, vol. 7, no. 13, 2018.

[13] N. Iqlima, "Analisis pengaruh inflasi, DPK dan tingkat suku bunga kredit modal kerja terhadap posisi kredit modal kerja: studi kasus pada bank persero," 2010.

[14] H. Natagera, "A.(2015). Pengaruh kredit UMKM terhadap pertumbuhan ekonomi regional di Indonesia. Artikel Departemen Ilmu Ekonomi Universitas Indonesia.".

[15] N. Ulandari, "Prospek dan Faktor-Faktor Yang Mempengaruhi Jumlah Kredit Yang Disalurkan BPR di Kota Denpasar," Skripsi Fak. Ekon. Udayana, 2009.

[16] T. Yustini, "Pengaruh Suku Bunga, Jumlah Perusahaan dan Pertumbuhan Ekonomi terhadap Penyaluran Kredit Modal Kerja bagi Umkm Di Sumatera Selatan," J. Keuang. dan Perbank., vol. 19, no. 3, p. 178663, 2015.

[17] O. M. Fahmy, M. Rustam, and E. Asmayadi, "Pengaruh Keuangan Inklusif Terhadap Kredit yang Disalurkan pada Sektor Usaha Mikro, Kecil dan Menengah di Indonesia," $J$. Ekon. Bisnis dan Kewirausahaan, vol. 5, no. 2, pp. 118-135, 2016. 